Acta vet. scand. $1976,17,495-500$.

From the Department of Pharmacology and Toxicology, Veterinary College of Norway, Oslo.

\title{
A COMPARISON OF SERUM CONCENTRATIONS OF PENICILLIN AFTER INTRAMUSCULAR INJECTION AND SUBCUTANEOUS AND DEEP INJECTION INTO THE DEWLAP IN CATTLE*
}

\author{
By \\ Torill Bergsjф
}

\begin{abstract}
BERGSJ $\emptyset$, T.: A comparison of serum concentrations of penicillin after intramuscular injection and subcutaneous and deep injection into the dewlap in cattle. Acta vet. scand. 1976, 17, 495-500. - Using an aqueous solution of sodium benzyl penicillin as the model substance, a comparison was made in cattle between absorption after intramuscular injection, and after subcutaneous and deep injection into the dewlap.

The duration of supposed therapeutically effective serum concentrations using the 2 dewlap routes was longer than for the intramuscular route, although maximum concentrations were lower. The applicability of injection into the dewlap, especially the subcutaneous route, is discussed in relation to intramuscular injection.
\end{abstract}

drug residues; intramuscular injection; subcutaneousinjection; dewlapinjection; serum concentrations; penicillin; absorption.

In recent years, steadily increasing attention has been paid to problems connected with residues at the injection site after intramuscular administration of drugs. The first preliminary studies were carried out by Rasmussen \& H $\phi g h$ (1971). Commonly used preparations of penicillin, streptomycin and tetracyclin, when administered in recommended dosages, could all be detected in varying concentrations at the injection site after the time limits laid down between injection and slaughter had elapsed. Local irritation could be observed to a greater or lesser degree up to 3

* This study was supported by the Norwegian Farmers Meat Marketing Organization. 
weeks after treatment (Svendsen 1972). Even though antibiotics may be absent from the kidneys and liver, there may, as pointed out by Rasmussen \& H $\phi g h$, be high concentrations present at the injection site. This has considerable implications when stipulating pre-slaughter time limits after treatment with antibiotics and chemotherapeutic drugs.

On this background, it would be advantageous if intramuscular injection could be avoided, both with regard to antibiotics and other drugs, and be replaced by alternative routes of administration. The aim of the present study was to investigate the suitability of the dewlap in cattle as an injection site, by comparing absorption after subcutaneous (s.c.) and deep dewlap injection with absorption after intramuscular (i.m.) injection. Anatomically, the dewlap can be described as a skin fold of varying size, containing loosely woven subcutaneous connective tissue with blood vessels, hair follicles, sebaceous and sweat glands, as well as an inner nucleus of fatty tissue, varying in size according to the age and state of nutrition of the animal.

\section{MATERIAL AND METHODS}

Sixteen Norwegian Red cows, all over 2 years, were divided into 3 groups: 8 cows for deep dewlap injection (needle 1.40 introduced as deeply as possible and directed towards the middle of the dewlap), 4 for s.c. dewlap injection, and 4 for i.m. injection (semimembranosus and semitendinosus muscles). The cows were all given 10,000 i.u./kg body weight of sodium benzyl penicillin, in a concentration of $250,000 \mathrm{i} . \mathrm{u}$./ml. This gives an average injection volume of $20 \mathrm{ml}$. Blood samples were taken from the jugular vein using non-heparinized vacutainers, at intervals of $1 / 2,1,2,4,8$ and 10 hrs. after administration of the penicillin. Serum penicillin concentrations were measured microbiologically according to the agar diffusion method as modified at the Department of Food Hygiene, Veterinary College of Norway (Yndestad 1975 personal communication). Two colonies of Sarcina lutea (ATCC 9341) were transferred from a blood plate into $10 \mathrm{ml}$ $0.9 \% \mathrm{NaCl}$. This suspension was then transferred into rehydrated Müller-Hinton agar, $1 \mathrm{ml}$ per $100 \mathrm{ml}$ medium. The agar was then poured into sterile petri dishes, forming an approx. $4 \mathrm{~mm}$ thick layer. Samples and standard were then dripped into $8 \mathrm{~mm}$ diameter wells stamped out in the agar, $0.1 \mathrm{ml}$ being placed into each well. The dishes were allowed to stand for $2 \mathrm{hrs}$. at room 
temperature for diffusion of penicillin into the medium, and then incubated at $37^{\circ} \mathrm{C}$ for $24 \mathrm{hrs}$. The method gives inhibition at levels down to 0.005 i.u. of penicillin added to the dish.

Samples taken after 8 and $10 \mathrm{hrs}$. were not diluted, samples taken after 1/2,1, 2 and 4 hrs. were diluted $1 / 10$ with phosphate buffer, $\mathrm{pH}$ 7.4. The standard was diluted with physiological saline. For verification of penicillin there was also made a parallel transfer to Müller-Hinton medium containing $1 \mathrm{ml}$ of penicillinase (2000 i.u. Bacto-penase, Difco) per $100 \mathrm{ml}$ medium.

\section{RESULTS}

1. Serum concentrations of penicillin after administration by the different routes are shown in Fig. 1, which gives average values and standard deviations. It is seen that both dewlap in-

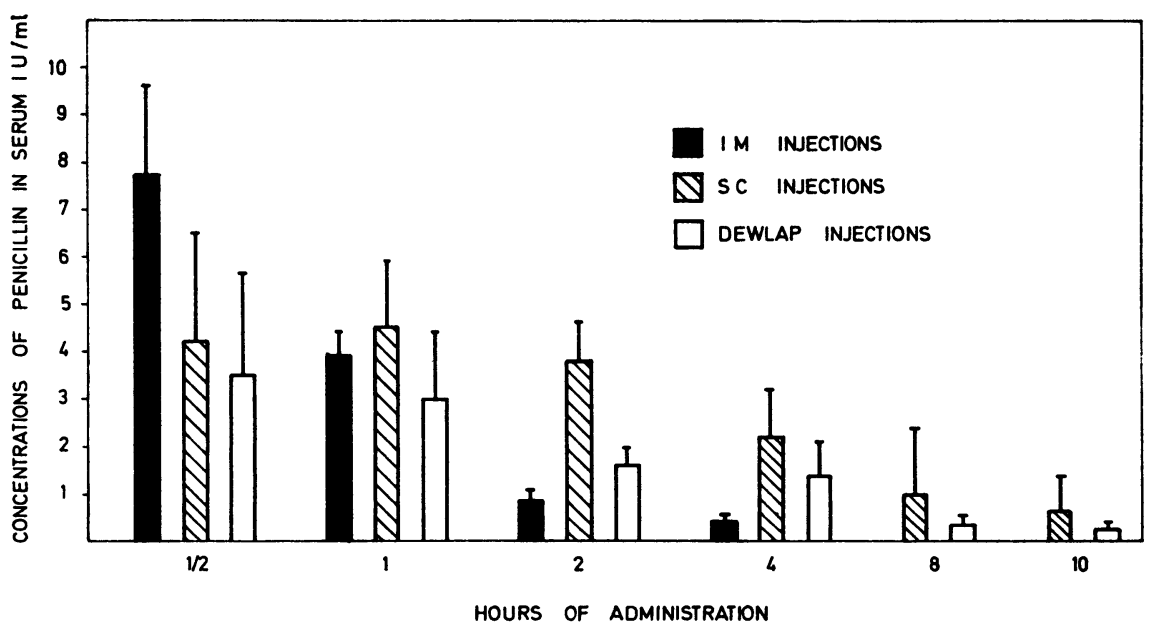

Figure 1. Comparison of serum concentrations (i.u./ml) of penicillin after intramuscular injection (i.m. inj.), subcutaneous injection into the dewlap (s.c. inj.) and deep injection into the dewlap (dewlap inj.). Dose of penicillin: 10,000 i.u./kg body weight.

jection routes show up to advantage as compared with the i.m. route. Although it is true that with the latter, initial concentrations are twice those found with the former, this state of affairs is equalized after $1 \mathrm{hr}$. With i.m. injection penicillin can no longer be detected after $8 \mathrm{hrs}$., while the 2 dewlap-injections give measureable values after $10 \mathrm{hrs}$. If the 2 dewlap injection routes are compared, it can be seen that s.c. injection shows a tendency 
to give higher serum concentrations. However, according to Wilcoxon's test, the difference is significant only after 2 and 8 hrs.

2. Local reaction after dewlap injection was judged by means of palpation and inspection. No clinically observable oedema occurred.

3. Half of the cows which received dewlap injections were slaughtered a fortnight after treatment. Local irritation, with limited haemorrhages and induration, was found after deep injection. The changed tissue measured about $3 \times 2 \times 1 \mathrm{~cm}$. Determination of penicillin residues in this tissue was not carried out.

\section{DISCUSSION}

The primary aim of these investigations was to compare absorption after s.c. and i.m. injection, having in mind a possible change-over to s.c. injection for suitable drugs and preparations. The site of injection should be localized to areas with large amounts of subcutaneous connective tissue as in the dewlap. Other subcutaneous injection sites rich in loosely woven connective tissue should also be investigated. In any case, the injection site should be standardized so that it may be located and removed at slaughter. At the same time it was of interest to compare the absorption of penicillin after deep dewlap injection with the 2 above-mentioned methods of administration.

The s.c. dewlap route has been employed by some veterinarians for the injection of inter alia calcium borogluconate and chinurid sulfate (Acaprin $\AA$ ), but as far as can be ascertained, no data is available in the literature concerning absorption from the dewlap. The s.c. dewlap route may be representative for s.c. injection in general. However, this is not necessarily the case, as vascularization and the amount of subcutaneous connective tissue vary with the localization, and this is of significance for absorption (Schou 1961).

As far as is known, the deep dewlap route has not been employed. This injection site could possibly be used for drugs and preparations which, because of local irritation, cannot be administrated subcutaneously. Injection into the dewlap has both advantages and disadvantages. One of the advantages is that the dewlap can be removed in its entity during the slaughter process, so that no problem will be created by any drug residues and changed tissue at the injection site. A disadvantage of the dewlap is 
that it is relatively difficult to approach without assistance to hold the animal. Although no significant local reactions were observed in these investigations, in which an aqueous solution of penicillin was used as the model substance, it is well known that oedema readily occurs in connection with dewlap injections.

Therapeutically effective serum concentrations of penicillin are stated to range from 0.1 to $1 \mathrm{i} . u . / \mathrm{ml}$ (Huebner 1971), depending inter alia on the type and localization of the infection. The results of the present work show that s.c. dewlap injection gives therapeutically effective serum concentrations of penicillin for twice as long a period as after i.m. injection. This is not in agreement with the comparative studies of Mercer et al. (1971) on the absorption of antibiotics from i.m. and s.c. injection sites. They found no significant differences in serum concentrations obtained after the 2 methods of administration. The reason for this disagreement could be based on 2 different circumstances. Mercer et al. employed procainpenicillin and benzathinpenicillin in contrast to the sodium benzylpenicillin used in the present investigation. This may have modified the absorption from the 2 injection sites to different degrees. Furthermore, Mercer et al.'s publication does not mention the site of the s.c. injections. This will, as previously mentioned, also be of significance.

The poorer utilization of penicillin when given by deep as compared with s.c. dewlap injection, must be considered to result from poor absorption from the dewlap, so that the last remnants of the depot are very slowly eliminated. Such slow release from i.m. injection sites is described by Mercer et al., who found penicillin in the urine 45 days after i.m. injection, and by Huebner who states that penicillin can be found in the urine 84 days after i.m. injection of benzathinpenicillin in the human.

\section{CONCLUSION}

From a pharmacokinetical viewpoint, s.c. injection in the dewlap is a valid alternative to i.m. injection of aqueous penicillin solutions. Investigations should also be carried out to find out if other s.c. injection sites rich in loosely woven connective tissue can be employed.

Deep dewlap injection should also be studied further, having in mind its use as an injection site for drugs and preparations which cannot be administrated subcutaneously. 
To the extent suitable preparations for subcutaneous use, and for deep dewlap injection can be developed, possibilities exist for the employment of subcutaneous and deep dewlap injection instead of the intramuscular route.

\section{REFERENCES}

Huebner, $R$. A.: Therapeutic serum concentrations of penicillin. J. Amer. vet. med. Ass. 1971, 159, 757-759.

Mercer, H. D., L. D. Rollins, M. A. Garth \& G. G. Carter: A residue study and comparison of penicillin and dihydrostreptomycin concentrations after intramuscular and subcutaneous administration in cattle. J. Amer. vet. med. Ass. 1971, 158, 776-779.

Rasmussen, F. \& P. H $\phi g h$ : Lokalirritation og koncentrationer på injektionsstedet efter intramusculær injektion af antibiotikaholdige præparater på $k \emptyset e r$ og grise. (Irritating effect and concentrations at the injection site after intramuscular injection of antibiotic preparations in cows and pigs). Nord. Vet.-Med. 1971, $23,593-605$.

Schou, J.: Absorption of drugs from subcutaneous connective tissue. Pharmacol. Rev. 1961, 13, 441-460.

Svendsen, 0. : Histologiske forandringer efter intramuskulære injektioner med antibiotikaholdige præparater. (Histologic changes after intramuscular injection with antibiotic preparations). Nord. Vet.-Med. 1972, 24, 181-185.

\section{SAMMENDRAG}

En sammenligning av serumkonsentrasjoner av penicillin etter intramuskulær injeksjon og subkutan og dyp injeksjon $i$ dogglappen på storfe.

Med benzylpenicillinnatrium i vandig løsning som modellsubstans er det foretatt en sammenligning av absorbsjonen etter intramuskulær injeksjon og injeksjon subkutant på og dypt i dogglappen hos storfe.

Varigheten av antatt terapeutisk effektive serumkonsentrasjoner er lengre for de to dogglappsinjeksjoner enn for den intramuskulære injeksjon, men maksimumskonsentrasjonen er lavere.

Anvendeligheten av dogglappsinjeksjoner, særlig den subkutane, diskuteres i relasjon til den intramuskulære injeksjon.

(Received November 11, 1976).

Reprints may be requested from: Torill Bergsj $\phi$, The Department of Pharmacology and Toxicology, Veterinary College of Norway, P. O. Box 8146, Oslo Dep., Oslo 1, Norway. 